\title{
Determination of PV Power and Battery Capacity Size for a Leisure Solar Powered Boat at Kalimas River, Surabaya, Indonesia
}

\author{
Ahmad Nasirudin ${ }^{1)^{*}}$, Hasanudin ${ }^{1}$, Danu Utama1), Lia Pundhi Tahwoto1) \\ ${ }^{1)}$ Department of Naval Architecture, Institut Teknologi Sepuluh Nopember, Surabaya 60111, Indonesia \\ *) Corresponding Author : anasirudin@gmail.com
}

\section{Article Info}

\section{Abstract}

\section{Keywords:}

Leisure Solar Powered Boat, PV Power,

Battery Capacity,

Linear programming

\section{Article history:}

Received: 30/07/20

Last revised: 29/10/20

Accepted: 29/10/20

Available online: 31/10/20

DOI:

https://doi.org/10.14710/kapal. v17i3.31965
As a green city, Surabaya had been developing a program of an environmentally friendly concept in almost all sectors. One of the developed sectors with this concept is the tourism area around the Kalimas river. Tour by riding a small passenger leisure boat is the most favorite recreational option. The leisure boat designs with environmentally friendly solar-powered concepts were developed, but regarding PV power and battery capacity determination, almost all designs are not optimal. This research is aimed to obtain the optimal PV power and battery capacity by calculating the number of PV panels and batteries with minimum cost. A Linear programming approach by Simplex method is applied in the optimization calculation. The results show that the number of the battery of the previous design can be reduced from 4 (four) units ( $20 \mathrm{kWh}$ ) becomes 3 (three) units ( $15 \mathrm{kWh}$ ) and the number of PV panels are still the same number with the previous one, i.e., 7 (seven) units $(2,24 \mathrm{~kW})$. The optimum system cost is around 264 million rupiahs, which means that the cost is reducing around 81 million rupiahs or $24 \%$.

Copyright (C 2020 KAPAL : Jurnal Ilmu Pengetahuan dan Teknologi Kelautan. This is an open access article under the CC BY-SA license (https://creativecommons.org/licenses/by-sa/4.0/).

\section{Introduction}

The system size of PV (Photovoltaics) power and battery capacity plays an essential role in designing the solar powered boat since the boat's performance in terms of endurance (cruising radius) depends on its PV power and battery capacity installed. The more PV panels and batties installed, the better the performance. However, the limitation of space area for PV panel placement and the battery weight become problems. The high investment cost for PV panels and batteries has also become an important issue. Therefore, the determination of the size of PV power and battery capacity for a Solar Powerd Boat is challenging [1].

The determination of PV and battery system size has been started to develop about two decades ago. However, it has been mostly developed for land applications where space and weight are not an issue. In 1994, Borowy and Salameh determined PV array size for a stand-alone hybrid wind/PV system using the least square method [2]. Followed by Kellog et al. in 1996, optimal sizing of a stand-alone hybrid wind/PV system coupled with battery storage, was investigated for a hypothetical site in Montana, U.S. [3]. An economic evaluation of a hybrid wind/PV/fuel cell generation system for a typical home in the Pacific Northwest was performed by Nelson et al. in 2005 [4].

A novel optimization sizing model for a hybrid solar-wind power generation system called HSWSO (the Hybrid SolarWind System Optimization Sizing) was introduced by Yang et al. [5]. Prasad and Natarajan also developed a new method for optimizing a wind/PV integrated hybrid system with battery storage for the site Pompuhar, Tamil Nadu state, India [6]. Another novel sizing method for determining the wind/PV system was developed by Hocaoglu et.al. The battery capacity was included in the optimization process to get the minimum cost [7].

The sizing determination of a more hybrid PV system which combined wind, PV, and diesel as power generation units were developed by Belfkira et.al. A deterministic algorithm was applied for optimization purposes [8]. Followed by Maleki dan Askarzadeh, the sizing of wind/PV/diesel system by using a discrete version of HS (Harmony Search) was applied for a site at Rafsanjan, Iran [9].

Meanwhile, some research on determining the PV power and battery capacity size for solar-powered boat application have been developed. Spagnolo et al. [10] designed a solar-electric boat for tourists where the PV power and battery capacity were determined by direct calculation. Nobrega and Rossling [11] developed a solar-powered boat for maximum energy efficiency, where the PV system was determined by using a simple calculation. 
Mahmud et al. [12] designed and fabricated an automated solar boat. The PV system size of the boat was determined by using direct calculation. Nasirudin et al. [13] developed an energy harvesting and battery management system for a solarpowered boat application. The system size was determined by direct calculation. Tukaram et al. [14] designed and fabricated a solar boat for tourism. Direct estimation was used for PV system size determination.

Nasirudin and Chao [15] developed a leisure solar-powered boat for Toba Lake, Indonesia, and Sun Moon Lake, Taiwan, where an optimization procedure using linear programming based on a specific boat mission was introduced. A more comprehensive study regarding PV power and battery capacity size determination was conducted by Nasirudin et al. in which the optimization of boat hull form was included into account [16].

Chao et al. [17] developed a solar-powered boat design using a standalone distributed PV system. Panprayun and Pitaksintorn [18] developed and evaluated the solar-powered catamaran for sustainable tourism in Southeast of the Gulf of Thailand. The PV system was determined by using direct estimation. Sunaryo and Ramadhani [19] designed an electrical system for a solar-powered electric recreational boat for Indonesian waters.

This research aims to obtain the optimum PV power and battery capacity sized (number of PV panel and battery) of solar-powered boat design for the Kalimas River application previously developed by Tahwoto [1]. The boat dimension is around 7.37-meter length, 2.5-meter breadth, and 0.35-meter draught. The boat is arranged to equip with four units of 320 kWh batteries and seven units of 320 watt PV panels by using direct calculation. In this current research, the optimization procedure which was developed by authors [15], [16] is adopted to re-calculate the PV system size.

\section{Methods}

\subsection{Research Object}

The research object is a developed design of a monohull solar-powered paddlewheel leisure boat, arranged to operate at Kalimas river Surabaya which was developed by Tahwoto [1]. The design specification and general arrangement of the boat are shown in Table 1 and Figure 1, respectively.

Table 1. Boat Particulars

\begin{tabular}{lll}
\hline Dimension & Notation & Value (m) \\
\hline Length overall (LoA) & 7.37 & $\mathrm{~m}$ \\
Breadth (B) & 2.5 & $\mathrm{~m}$ \\
Draft (T) & 0.35 & $\mathrm{~m}$ \\
Height (H) & 0.8 & $\mathrm{~m}$ \\
No. of passenger & 12 & persons \\
Service Speed (Vs) & 5.4 & knots \\
Endurance & $15(3.75)$ & round trips (hrs) \\
Motor Power & $2 \times 1.8$ & $\mathrm{~kW}$ \\
Battery Capacity & $4 \times 5$ & $\mathrm{kWh}$ \\
PV Power & $7 \times 320$ & $\mathrm{~W}$ \\
Cost of PV Panels \& batteries & 345 & million-rupiahs \\
\hline
\end{tabular}

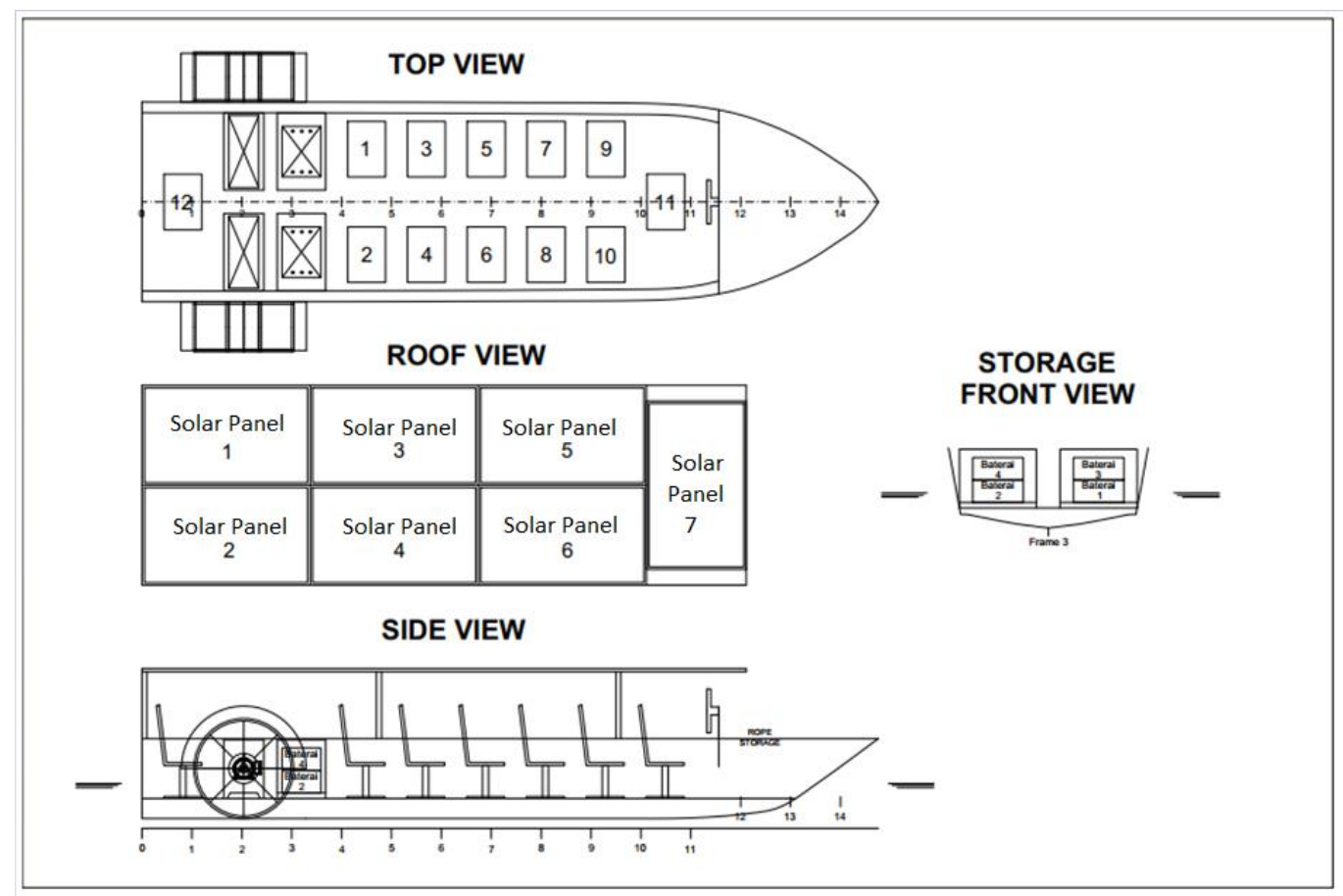

Figure 1. General Arrangement of Kalimas River's Solar Power Boat Design 


\subsection{Optimization Procedure and Formulation}

This procedure focuses on optimizing the system size, i.e., determining the number of PV panels and batteries of the existing boat design. The procedure of the optimization in this current research can be seen in Figure 2.

\subsubsection{Displacement and Propulsion Power Relationship}

The displacement of the boat depends on its draft, which represents the total weight of the boat. It becomes an essential part of this process. The displacement will influence the boat's propulsion power, influencing the determination of the PV panel and battery number. In contrast, the number of PV panels and batteries itself produces the additional weight, which will affect the displacement. It means that this is an iterative process.

The relation between the additional weight (PV and battery weight) and the propulsion power is obtained from the regression of propulsion power at the different draft with service speed condition of 5.4 knots of the existing design. Its relation is expressed in the following equation.

$$
P_{\text {prop }}=0.15 w_{s}+3.48
$$

where $P_{\text {prop }}$ is propulsion power $(\mathrm{kW})$ and $w_{s}$ denotes the system weight or the weight of PV panels and batteries $(\mathrm{kg})$.

\subsubsection{Energy Demand}

The energy demand is calculated based on the required propulsion power at a particular operational time duration. The following equation can express the calculation of energy demand.

$$
E_{\text {load }}(t)=\int_{0}^{t} P_{\text {prop }}(t) \cdot d t ; \quad t=0,1,2, . .24
$$

where $E_{\text {load }}$ is energy demand in $\mathrm{kWh}, P_{\text {prop }}$ is the required propulsion power in $\mathrm{kW}$, and $\mathrm{t}$ is the operational time duration in hours.

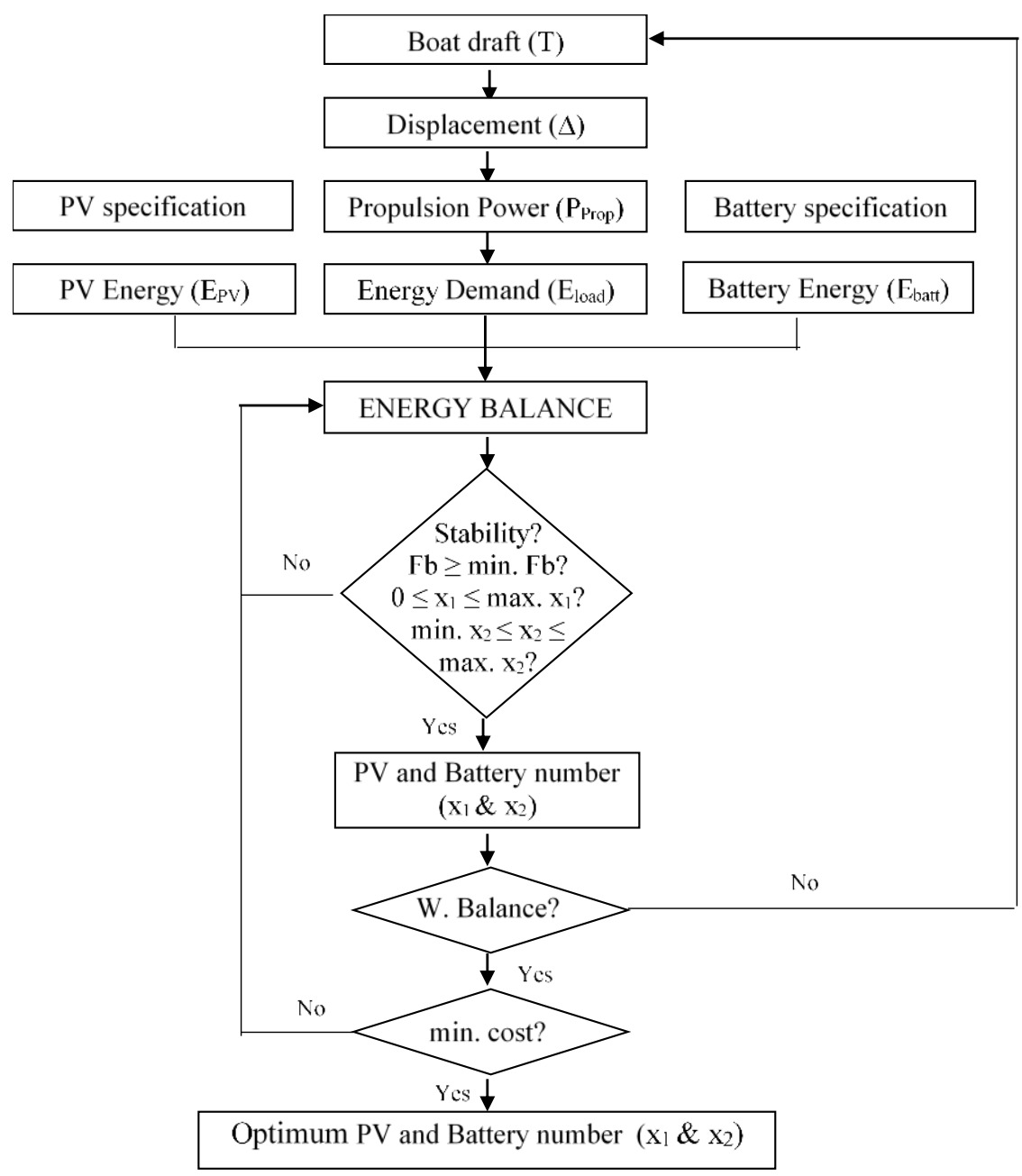

Figure 2. Optimization Procedure 


\subsubsection{PV Energy}

PV energy means the energy harvested by PV panels from the sun. It is influenced by several factors such as the sun irradiance where the boat operated, the specification and number of PV panel, and the system efficiency, which cause energy losses. The PV energy formulation is shown in the following equation.

$$
E_{P V}(t)=\frac{P_{P V}}{1000} \cdot \eta_{s} \cdot \eta_{c} \cdot x_{1} \int_{0}^{t} \frac{I_{r r}(t)}{G_{S T C}} d t ; \quad t=0,1,2, . .24
$$

where $P_{P V}$ is PV peak power of each panel in watt, $\eta_{c}$ is charging efficiency, $\eta_{s}$ is PV system efficiency, $I_{r r}$ is sun irradiation (insolation) in $\mathrm{kWh} / \mathrm{m}^{2}, G_{S T C}$ is a constant with the value of $1 \mathrm{~kW} / \mathrm{m}^{2}$ which is the solar irradiance at standard test condition, $t$ is operational time duration (hr), and $x_{1}$ is the number of PV panel which is a variable has to be found in the optimization process.

In this research, $\mathrm{PV}$ panel specification is taken as the same specification from previous design with $P_{P V}$ about 320-Watt peak power, while $\eta_{c}$ is assumed about $85 \%$ and $\eta_{s}$ is about $80 \%$. While regarding the sun irradiation $\left(I_{r r}\right)$ is about $5 \mathrm{~kW} / \mathrm{m}^{2}$ which is an average of daily irradiation at Surabaya [20]. To present the daily irradiation become hourly irradiance, then an approach introduced by Jain [21] is applied.

\subsubsection{Battery Energy}

The battery energy is obtained from the balance of the energy, which is the absolute value of the maximum deficit between energy supplied by PV panels (EPV) and energy demand (Eload) at a certain time. The formulation of energy balance, as shown in the following equation.

$$
E_{\text {batt }}=\left|\max \left(E_{P V}(t)-E_{\text {load }}(t)\right)\right|
$$

To obtain the number of required batteries (x2) then Eq. 5 is applied for this optimization. It considers the specification of battery, energy lost during the discharging process, and allowed minimum remaining capacity of the battery.

$$
x_{2}=\frac{E_{b a t t} \cdot 1000}{V_{b a t t} \cdot C_{b a t t} \cdot \eta_{d}(1-S O C)}
$$

where $V_{\text {batt }}$ and $C_{\text {batt }}$ are the individual voltage (volt) and capacity of the battery (Ampere-hour), respectively. $\eta_{d}$ is battery discharge efficiency that represents the energy lost during the energy discharging process, and SOC (State of Charge) is the minimum remaining capacity of battery allowed.

In the current research, battery specification is taken as the same specification from the previous design i.e. Li-Ion battery with $V_{\text {batt }}$ about 48 volts, $C_{\text {batt }}$ about $104 \mathrm{Ah}$ (or $5 \mathrm{kWh}$ ), while $\eta_{d}$ is assumed about $85 \%$ and SOC is about $80 \%$ where is the type of Li-Ion battery.

\subsubsection{Weight Balance}

Since the number of PV panels and battery (additional weight) will affect the ship propulsion power, and the power itself will affect the PV and battery number's determination, then the balance condition (no further additional weight changing) has to be fulfilled. The following equation expresses the weight balance formulation.

$$
\left(w_{s}\right)_{i+1}=\left(w_{s}\right)_{i}
$$

$w_{s}$ is system weight i.e. ( $\mathrm{w} 1 \mathrm{x} 1+\mathrm{w} 2 \mathrm{x} 2$ ), where $\mathrm{w} 1$ and $\mathrm{w} 2$ are the unit weight of an individual PV panel and battery respectively, while $\mathrm{i}$ is the $\mathrm{i}$-th iteration. From the previous design, $\mathrm{w} 1=18.7 \mathrm{~kg}$ and $\mathrm{w} 2=36.5 \mathrm{~kg}$.

\subsubsection{Optimization}

Linear programming by the simplex algorithm is chosen for this research. The objective is to obtain the number of PV panel and battery with minimum investment cost. The formulation of the objective function is shown in Eq. 7-9.

$$
\begin{gathered}
\text { min. } \operatorname{cost}_{P V}+\operatorname{cost}_{\text {batt }} \\
\operatorname{cost}_{P V}=c_{1} x_{1} \\
\operatorname{cost}_{\text {batt }}=c_{2} x_{2}
\end{gathered}
$$

$c_{1}$ is the unit cost of an individual PV panel (Rp) and $c_{2}$ is the unit cost of the battery (Rp). $x_{1}$ and $x_{2}$ are the variables which represent the number of PV panel and battery respectively. In this case, from the previous design, the unit cost of PV panel $\left(c_{1}\right)$ and battery $\left(c_{2}\right)$ is 3 million and 81 million rupiahs.

Some constraints are considered to reach the objective. The first constraint is the minimum freeboard presented by the maximum additional weight or system weight allowed. The constraint is expressed in the following equation. 


$$
w_{s} \leq w_{s} \max
$$

$w_{s}$ is the system weight $(\mathrm{kg})$ and $w_{s}$ max is the maximum system weight allowed $(\mathrm{kg})$. By following the regulation from NCVS (Non-Convention Vessel Standard Indonesian Flagged) [22]. The minimum freeboard for this boat is about $150 \mathrm{~mm}$ which equals $5300 \mathrm{~kg}$ of the maximum additional weight $\left(w_{s} \max \right)$.

The second constraint is ship stability. The maximum allowed KG (the vertical distance of the center of gravity) is considered a stability requirement. The constraint regarding boat stability is expressed in the following equation.

$$
K G_{0}+\frac{h_{1} w_{1} x_{1}+h_{2} w_{2} x_{2}}{w_{1} x_{1}+w_{2} x_{2}} \leq K G_{\max }
$$

$K G_{0}$ is the initial vertical distance of the center of gravity excluding PV panels and batteries, $K G_{\max }$ is maximum $K G$ refers to the regulation, and $h_{1}$ and $h_{2}$ are the vertical distance of PV module and battery from keel respectively. In this case, KG0 is $0.54 \mathrm{~m}$., while $h_{1}$ and $h_{2}$ are $0.37 \mathrm{~m}$ and $1.5 \mathrm{~m}$, respectively. Using NCVS stability criteria, the average $K G_{\text {max }}$ with additional weight up to $5300 \mathrm{~kg}$ is around 0.571 meter.

The third constraint is the maximum number of PV panels. The maximum number of PV depends on the available space on the roof of the boat. The constraint regarding the maximum PV panels number is expressed in the following equation.

$$
0 \leq x_{1} \leq x_{1 \max }
$$

$x_{1 \text { max }}$ is the maximum number of PV panels where can be identified from the general arrangement drawing of the previous design. In this case, the maximum number of PV panels is around 7 (seven) units.

The last constraint is the number of batteries. The minimum number of battery is calculated based on the energy balance equation, and the maximum is the required number of battery when the boat without PV Panel. It is equal to 4 (four) units (previous design). The constraint of the battery number can be seen in the following equation.

$$
\frac{\left|\min \left(E_{P V}-E_{\text {load }}\right)\right| \cdot 1000}{V_{\text {batt }} \cdot C_{\text {batt }} \cdot \eta_{d}(1-S O C)} \leq x_{2} \leq x_{2 \max }
$$

\section{Results and Discussion}

The operating cost of a solar powered boat can be cheaper than a boat with a conventional propulsion system, but the investment cost of solar powered boat propulsion system is much more expensive since the cost of PV panels and batteries is still high [14]. Therefore, efficient PV power and battery capacity size are important to reduce its investment cost. Currently, almost all of the PV system size on a solar-powered boat is determined by direct calculation and could lead to inefficient investment costs. By using optimization procedures, efficient investment costs can be reached.

Based on the results of the optimization process that has been carried out on the previous design [1] that the number of PV panels are 7 (seven) units where is equal to 2,24 kW of PV power, and the number of batteries is 3 (three) units or equal to $15 \mathrm{kWh}$ battery energy capacity with the investment cost around 264 million rupiahs (Figure 3 ). Compared to the previous design, the number of PV panels is the same, while the number of batteries is less than before. The optimum results can reduce the system cost by around 81 million rupiahs or $24 \%$.

Optimization results show that the investment cost still can be reduced by adding the number of PV panels and reducing the number of batteries until a specific value. Figure 3 shows that the most minimum cost can be obtained at the PV number around 18 units ( $4.14 \mathrm{~kW})$ and the number of batteries around one unit ( $5 \mathrm{kWh}$ ). However, the condition of the operating area in Kalimas river, which has several bridges, causes the size of the ship and its canopy to be limited. Therefore the most optimal result cannot be applied for this boat.

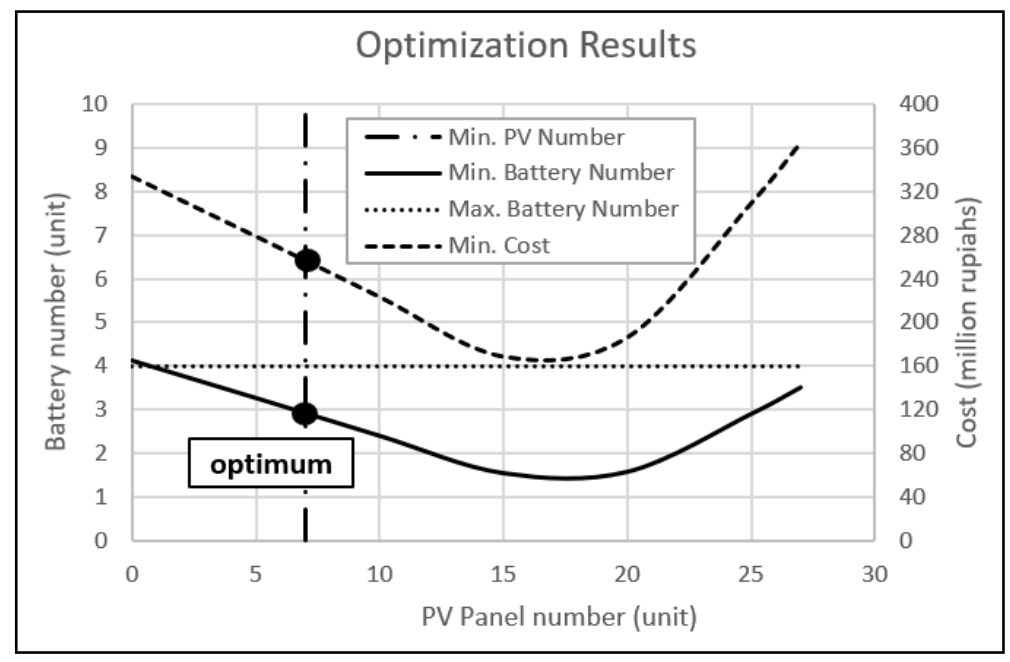

Figure 3. Optimization Results 


\section{Conclusion}

From this optimization process can be concluded that the number of the battery of the previous design can be reduced from 4 (four) units ( $20 \mathrm{kWh}$ ) become 3 (three) units ( $15 \mathrm{kWh}$ ). In contrast, the number of PV panels is still the same as the previous one, i.e., 7 (seven) units $(2,24 \mathrm{~kW}$ ). The new system cost is 264 million rupiahs, which means that the cost is reducing around 81 million rupiahs or $24 \%$.

\section{Acknowledgements}

This work is supported under "Department Funding Research" with contract No.1633/PKS/ITS/2019, Department of Naval Architecture, Faculty of Marine Technology, Institut Teknologi Sepuluh Nopember, Surabaya, Indonesia.

\section{References}

[1] L. P. Tahwoto, A. Nasirudin and D. Utama, "Desain Konsep Solar Powered Boat dengan Penggerak Paddle Wheel untuk Wisata Sungai Kalimas Surabaya," Departemen Teknik Perkapalan, Institut Teknologi Sepuluh Nopember, Surabaya, 2019.

[2] B. S. Borowy and Z. M. Salameh, "Optimum Photovoltaic Array Size for a Hybrid Wind/PV System," IEEE Transaction on Energy Conversion, vol. 9, no. 3, pp. 482-488, 1994.

[3] W. Kellog, M. H. Nehrir, G. Venkataramanan and V. Gerez, "Optimal Unit Sizing for a Hybrid Wind/Photovoltaic Generating System," Electric Power Systems Research, vol. 39, pp. 35-38, 1996.

[4] D. B. Nelson, M. H. Nehrir and C. Wang, "Unit Sizing and Cost Analysis of Stand-alone Hybrid Wind/PV/Fuel Cell Power Generation Systems," Renewable Energy, vol. 31, pp. 1641-1656, 2006.

[5] H. Yang, L. Lu and W. Zhou, "A Novel Optimization Sizing Model for Hybrid Solar-Wind Power Generation System," Solar Energy, vol. 81, pp. 76-84, 2007.

[6] A. R. Prasad and E. Natarajan, "Optimization of Integrated Photovoltaic-Wind Power Generation Systems with Battery Storage," Energy, vol. 31, pp. 1943-1954, 2006.

[7] F. O. Hocaoglu, O. N. Gerek and M. Kurban, "A Novel Hybrid (Wind-Photovoltaic) System Sizing Procedure," Solar Energy, vol. 83, pp. 2019-2028, 2009.

[8] R. Belfkira, L. Zhang and G. Barakat, "Optimal Sizing Study of Hybrid Wind/PV/Diesel Power Generation Unit," Solar Energy, vol. 85, pp. 100-110, 2011.

[9] A. Maleki and A. Askarzadeh, "Optimal Sizing of a PV/Wind/Diesel System with Battery Storage for Electrification to an Off-grid Remote Region: A Case Study of Rafsanjan, Iran," Sustainable Energy Technologies an Assessments, vol. 7, pp. 147-153, 2014.

[10] G. S. Spagnolo, D. Papalillo, A. Martocchia dan G. Makary, "Solar-Electric Boat," Journal of Transportation Technologies, vol. 2, pp. 144-149, 2012.

[11] J.C. d. C. Nóbrega dan A. Rössling, "Development of Solar Powered Boat for Maximum Energy Efficiency," International Conference on Renewable Energies and Power Quality (ICREPQ' 12), Santiago de Compostela (Spain), 2012.

[12] K. Mahmud, S. Morsalin dan M. I. Khan, "Design and Fabrication of an Automated Solar Boat," International Journal of Advanced Science and Technology, vol. 64, pp. 31-42, 2014.

[13] A. Nasirudin, R. M. Chao and S. X. Chen, "Energy Harvesting and Battery Management Systems Development for a Solar Powered Boat Application," in The 9th International Conference on Marine Technology (MARTEC), Surabaya, 2014.

[14] S. Tukaram, S. R. Uttam, R. Shivaji, N. Ankush dan K. Kare, "Design and Fabrication of a Solar Boat," International Journal of Innovations In Engineering Research And Technology [IJIERT], vol. 3, no. 1, pp. 1-4, 2016.

[15] A. Nasirudin and R. M. Chao, "Mission Based Optimization Design of the PV Harvesting and Storage System for a Solar Powered Boat," in Proceeding of 7th PAAMES and AMEC, Hong Kong, 2016.

[16] A. Nasirudin, R. M. Chao and I. K. A. P. Utama, "Solar Powered Boat Design Optimization," in Procedia Engineering, 2017.

[17] R.-M. Chao, H.-K. Lin dan C.-H. Wu, "Solar-powered boat design using standalone distributed PV system," Proceedings of 4th IEEE International Conference on Applied System Innovation 2018 ( IEEE ICASI 2018 ), Chiba, Japan, 2018.

[18] G. Panprayun dan S. Pitaksintorn, "Development and evaluation of solar powered catamaran for sustainable tourism in southeast of the gulf of Thailand," INTERNATIONAL JOURNAL of RENEWABLE ENERGY RESEARCH, vol. 8, no. 2, pp. 1124-1129, 2018.

[19] S. Sunaryo dan A. W. Ramadhani, "Electrical system design of solar powered electrical recreational boat for Indonesian waters," The 3rd International Tropical Renewable Energy Conference "Sustainable Development of Tropical Renewable Energy" (i-TREC 2018), 2018.

[20] M. Rumbayan, A. Abudureyimu dan K. Nagasaka, "Mapping of Solar Energy Potential in Indonesia Using Artificial Neural Network and Geographical Information System," Renewable and Sustainable Energy Reviews, vol. 16, pp. 1437-1449, 2012.

[21] P. C. Jain, "Estimation of Monthly Average Hourly Global and Diffuse Irradiation," Solar and Wind Technology, vol. 5, no. 1, p. $7-14,1988$. 
[22] Kementerian Perhubungan Republik Indonesia, "Load Line," dalam Non-Convention Vessel Standard Indonesian Flagged, Jakarta, Kementerian Perhubungan Republik Indonesia, 2009, pp. VI-36. 